\title{
Problems of Dyslexia, Dyspraxia and Dysgraphia in the Development of Written Speech of English in Higher Education and Methodological Recommendations for Its Solution
}

\author{
Nilufar Ulashovna Mustafaeva \\ Lecturer, Termez State University, Uzbekistan \\ http://dx.doi.org/10.18415/ijmmu.v8i10.3078
}

\begin{abstract}
While learning a foreign language is so important to keep fluency and accuracy. Being knowledgeable in any aspects, literacy skills of foreign languages will influence on our personal growth and professional development. Thus, researchers have been intensively investigating the phenomenon of reading and spelling disorders in learning and teaching foreign languages and, the ways of helping them. There many valuable reasons. Namely, it helps to improve self-confidence self-esteem and brain health. Pupils learn how to be confident to make speech around others and it helps to enhance ones knowledge of foreign languages structures and vocabulary. As well as that, pupils and students develop their analytical thinking. In addition, it is very useful for their financial life that they can expand their job and career opportunities and increase their earn power. Of course there some difficulties with learning foreign languages. We can see that problems with learning English there are dyslexia, dyspraxia and dysgraphia. However, we can use valuable methods for struggling with them.
\end{abstract}

Keywords: Dyslexia; Dyspraxia; Dysgraphia; Skill; Pronounce; Writing; Reading

\section{Introduction}

Firstly, we will investigate the speech difficulties. Language difficulties is considered as a learning disorder that manifests itself with serious difficulties in acquiring and using listening, speaking, reading, writing, thinking, and mathematical skills. Children who suffer from dyslexia during their primary school can face to many problems with learning new languages because of their undeveloped ability. However, this does not indicate problems with their level of intelligence. It also occurs in children with very high levels of intelligence. 
Nevertheless, sometimes the disease is ignored. The first signs of dyslexia were taken in 1896 by the English physician W.Pringle Morgan and published in the British Medical Journal. In his article, Morgan said that a 14-year-old boy named Percy was always smarter and, faster than his peers in games and not lagging behind his friends in anything, but could not read (www.dyslexia.uz).

Children diagnosed with dyslexia should be helped as much as possible during education. The problem is that the child is supported by special education services in their field and succeeds in a normal classroom environment. At this stage, the family's task is to ensure the self-confidence of the child who is shaken by the difficulty. The child needs to make sure that the problem is not his fault and that he has strengths (Umran).

Digraphia is a unique reading ability that causes problems with writing. There are three types of digraphia, each of which develops from a disorder of internal memory. Dysgraphia can cause a variety of individual or collective symptoms, such as incorrect spelling or capitalization. A person with dysgraphia often has little control over the size and spacing of the letters. They may take longer to write than the average person, and thus may express discomfort or stress.

People with dysgraphia can also have dyslexia, which can lead some people to confuse their symptoms. Usually, dysgraphia is caused by problems with working memory. People with this disease are unable to make connections between the brains regions needed to develop writing skills. This can affect spelling coding, spelling cycle, and graph motor output.

So how can you know if you are catching this illness?

To match your child with the right dyslexia program, a doctor or educational specialist will do tests to see how well they read and write. An educational psychologist can also do tests to find out if their learning issues are due to problems like depression or ADHD.

Once you have a firm diagnosis, you can work with your child's doctor, teacher, and educational specialists to create a learning plan. Talk to your child's school about getting help to address their unique learning needs. The law requires schools to set up special learning plans, called Individualized Education Plans (IEPs), for kids with learning disorders like dyslexia. An IEP describes your child's needs and how the school will help meet them. You and the school will update the plan each year based on your child's progress. Extra help for kids with dyslexia can include:

Special education. A learning specialist or reading specialist can do one-on-one or group sessions, either in the classroom or in a separate room in the school.

Accommodations. An IEP outlines special services your child needs to make school easier. These might include audio books, extra time to finish tests, or text-to-speech a technology that reads words aloud from a computer or book. School is not the only place where your child can learn. You can also help foster reading and writing skills at home. Read with your child whenever you can. Help them sound out words they have trouble with.

What Are the Treatments for Dyslexia?

Medically Reviewed by Amite Shroff, MD on March 22, 2021 
If your child has dyslexia, a few different treatments can improve their ability to read and write. Some programs also help kids catch up to their peers in school. The younger children are when they start treatment, the better their odds of success. However, even adults with dyslexia can continue to improve their skills with the right help. Dyslexia treatments are targeted to each person. Your child will work with one or more specialists to develop a program that meet their unique needs.

Tests for Dyslexia

To match your child with the right dyslexia program, a doctor or educational specialist will do tests to see how well they read and write. An educational psychologist can also do tests to find out if their learning issues are due to problems like depression or ADHD. Once you have a firm diagnosis, you can work with your child's doctor, teacher, and educational specialists to create a learning plan.

Reading Programs

Kids with dyslexia have trouble matching letters with the sounds they make, and matching words with their meanings. They need extra help learning to read and write.

\section{TOP PICKS}

Puberty: How Young Is Too Young?

How Chickenpox Is Spread

Developmental Delays in Children Ages 3-5

What to Do If You are Child Is Constipated

Does Your Child Have Allergy Symptoms?

Why Is My Child Breathing So Fast?

Your child can work with a reading specialist to learn how to:

Sound out letters and words ("phonics")

Read faster

Understand more of what they read

Write more clearly

A couple of reading programs are geared toward kids with dyslexia. They are:

Orton-Gillingham. This is a systematic technique that teaches kids how to match letters with sounds, and recognize letter sounds in words. 
Multisensory instruction teaches kids how to use all of their senses - touch, sight, hearing, smell, and movement - to learn new skills. For example, your child might run their finger over letters made out of sandpaper to learn how to spell.

Extra Help

Talk to your child's school about getting help to address their unique learning needs. The law requires schools to set up special learning plans, called Individualized Education Plans (IEPs), for kids with learning disorders like dyslexia. An IEP describes your child's needs and how the school will help meet them. You and the school will update the plan each year based on your child's progress.

Extra help for kids with dyslexia can include:

Special education. A learning specialist or reading specialist can do one-on-one or group sessions, either in the classroom or in a separate room in the school.

Accommodations. An IEP outlines special services your child needs to make school easier. These might include audio books, extra time to finish tests, or text-to-speech a technology that reads words aloud from a computer or book.

School is not the only place where your child can learn. You can also help foster reading and writing skills at home. Read with your child whenever you can. Help them sound out words they have trouble with (American Academy of Pediatrics: 2003).

\section{Learning Strategies}

These tips can help both kids and adults with dyslexia:

- $\quad$ Read in a quiet place with no distractions.

- $\quad$ Listen to books on CD or computer, and read along with the recording.

- $\quad$ Break up reading and other tasks into small pieces that are more manageable.

- $\quad$ Ask for extra help from your teacher or manager when you need it.

- Join a support group for kids or adults with dyslexia.

- $\quad$ Get plenty of rest and eat healthy foods.

As your child gets older, they will learn how to manage their dyslexia. A learning disorder should not stop them from excelling in school, going to college, or later having a successful career (Kids Health).

As well as that, many learners are facing to dysgraphia during learning foreign languages. Here is followed causes and treatments for these illness.

If dysgraphia appears in childhood, it is usually the result of a problem with orthographic coding. This is an aspect of working memory that allows you to permanently remember written words, and the way your hands or fingers must move to write those words. 
With dysgraphia, kids or adults have a harder time planning and executing the writing of sentences, words, and even individual letters. It is not that you do not know how to read, spell, or identify letters and words. Instead, your brain has problems processing words and writing.

When dysgraphia develops in adults, the cause is usually a stroke or other brain injury. In particular, injury to the brain's left parietal lobe may lead to dysgraphia. You have a right and left parietal lobe in the upper part of your brain. Each is associated with a range of skills, such as reading and writing, as well as sensory processing, including pain, heat, and cold (Dysgraphia: 2018).

Occupational therapy may be helpful in improving handwriting skills. Therapeutic activities may include:

- Holding a pencil or pen in a new way to make writing easier

- Working with modelling clay

- Tracing letters in shaving cream on a desk

- Drawing lines within mazes

- Doing connect-the-dots puzzles

There are also several writing programs that can help children and adult is form letters and sentences neatly on paper (International Dyslexia Association: 2018).

Look for other therapists or resources in your community that may help. You may need to be an aggressive advocate for your child, but keep in mind that there are laws and school policies designed to serve students with all types of learning challenges.

\section{References}

American Academy of Pediatrics. (2003) Red Book Report on the Committee of Infectious Diseases

(American Academy of Pediatrics Committee on Infectious Diseases/Report of the Committee on Infectious Diseases), "Fifth Disease (Parvovirus B19)."

Carol Dweck. Mind sets the new success of psychology.

Coping with Dyslexia, Dysgraphia and ADHD: A Global Perspective.

International Dyslexia Association. (2018). Understanding dysgraphia.

Kids Health: "Fifth Disease."

Umran. Oral-Fearless. Recognition of learning problems in preschool age.

www.dyslexia.uz 


\section{Copyrights}

Copyright for this article is retained by the author(s), with first publication rights granted to the journal.

This is an open-access article distributed under the terms and conditions of the Creative Commons Attribution license (http://creativecommons.org/licenses/by/4.0/). 